\title{
The prioritization of obstacles in the application of the suggestions system from employees view Case study: "Education organization of Kermanshah province"
}

\author{
Masoud Nouri \\ Department of Engineering, Eslam abad Gharb Branch, Razi University, Kermanshah, Iran.
}

\begin{abstract}
This research aims to prioritize obstacles in the application of the suggestions system from employees view (case study: Kermanshah province ministry of Education), It is of the descriptive in type in which the library and applied study methodologies as well as one group T-test are used and the Freedman test is utilized in order to prioritize factors and the anthropic method is used to prove the ranking which the sample data is the whole employees of the organization and 195 people were chosen through kook ran sampling method who answered the items in the questionnaire. The results show that in prioritizing obstacles in the application of the system of suggestions in cooperative management, the obstacles emanated from employees come first and those of management come second and those oh organization and structure come third and fourth respectively.
\end{abstract}

Key words: - cooperation $₫$ suggestion $₫$ suggestions system $₫$ obstacles in the application of suggestions system $₫$ prioritization

\section{INTRODUCTION}

Regarding to changes in management in 30 recent decades show. Thinkers and managers efforts for finding suitable solutions. Raising of approaches and new managements techniques, cooperative management, process engineering virtual departments and etc., show that thinkers is for finding a new method that can be as a managing tool and to manage organization s complicated world. Cooperative management was raised at 50's in Japan and also is one of the best managing methods and also is dynamic way for employee's cooperation. This method uses of employees and customer creativity and novelty in the ideal way. Cooperation defined as amity and affording for be better. Manpower is an important tool for acquiring aims in any organization, and because man has thought, creativity and novelty, to be counted as main capital, and thought power of employees, individuals and customers in department to be counted as hidden (secret) and statics capital. I spite of other surceases, Nan power not decrease with con summing and amount that man uses of his thought power as his ability will improve. People that to cooperate in organization s activities and uses of his pure thought, in addition to improving of organization, also they to become lofty. In department view, cooperative management defends creating of environment those employees, supplier's customers and stockholders can cooperate in new suggestion and thoughts, to solving of problem, making decisions and helping to management, and the other word to cooperate in all of the tasks. Cooperation and cooperative management isn $t$ a new phenomenon in department s management, but it ${ }^{\text {s }}$ thought was raised in management theories in the late of $19^{\text {th }}$. (Ahanchi, 2008).

This method is basis of voluntary cooperation of employees, suppliers, and customers and wants uses of their thoughts, opinions and creativity for solving of problems and until organization s management has not been believed to employee's cooperation, cooperative management not to become a reality (Alvani, 2006).

There are many different mechanisms for exciting of cooperative management that the most technique is establishing of suggestion system. Suggestion system is a technique that can use of employees, suppliers and customer's thought for solving of problems. In the basis of suggestion system all of employees, and customers in the highest level to the lowest level can suggest their ideas, novelties' and suggestion for solving of problems and improving of tasks or increasing of productions quality. (Ahanchi, 2008)

\section{DISCUSSION}

The aim of this research is that whit identifying of problem and suggestion system obstacles, consciously to solve these problems. Also Kermanshah province ministry of Education can reach to high aims regarding to organizing and managing of employees in cooperative management path and making collective decision and also to use of employee's creativity.

In fact suggestion system with attention to it ${ }^{\mathrm{s}}$ results in different countries and organizations is a basic and fundamental change in departments. 
With regard to slow trend of suggestion system ${ }^{\mathrm{s}}$ execution in Kermanshah province ministry of education in 2008 , per capita employees suggestion was 0.023 , while in other countries and developed companies, it is ten teams more than our country, and this show that suggestion system in department has not been excited effectively and has many obstacles. So the main problem in this research is that. Are there obstacles for execution? Hossain Yosefi khosroghi believes that execution of suggestion system in department effected by four factors that are: managing, systemic, raised from employees and cultural- structural. Survey of these four Factors is as following:

\subsection{Managing obstacles of suggestion system:}

managing styles of department styles of department with cooperative system, manager is live to suggestion system. Managing support of suggestion system, managers training about suggestion system, making a managing decision, manager's status, and manager's riskiness.

\subsection{Systematic obstacle of suggestion system :}

behavior of executive committee about of suggestion system's acceptance, suitable advertisements, on time payment reward to suggestion, exact surrey of suggestion, executive rule, existence of efficient employees in executive committee, on time execution of approved suggestions.

\subsection{Cultural- structural obstacles of suggestion system}

complexity of systemic duties that to limit suggestion's background, the lock of suitable situation of suggestion system in department, clarifying of suggestion system's aims for employees, the extent of department, deterring of employees duties, complexity, to be specialized and to monopolized of department activities and inattentive to managing and exporting education .

\subsection{Employees' obstacles of suggestion system:}

existence of sufficient information for suggesting of suitable suggestions, employees believe to effectiveness of suggestion system, employees awareness of suggestion system, existence of mutual trust between the employees, trending to cooperative work and cooperation in decisions, knowledgeable employees, and employees' attachment to department.

\section{IMPORTANCE OF RESEARCH}

This research with regard to importance of cooperation and existence of good manpower in organizations, want to find obstacles that had limited this talent in salient in solving of problems, and also in classifying of them. Cooperation is a main key for manpower extension and cultural extension of manpower is a main goal and main factor force economic extension. So can say that man power cooperation is a motive force for economic extension but on the condition that manpower has been motivation, creativity and safety. (Ahanchi 2008)

A successful suggestions system to be promoted by employees and to say that what make a good suggestion, because some of whatever that are suggestion, in face is employees' routine program. Departments know that employee's ideas and knowledge are valuable source and suggestions system is a good way for acquiring to this source. Also this system is aware extensive part of department that to encourage employees' systematic cooperation for solving of problems. In any department management is creating of motivation and providing of suitable environment for employees, in order to that be able to show their abilities. Establishment of suggestions system is one of the ways for manpower management and uses for maintenance of man reputation and work improvement (Bayan ko.2006)

The use of suggestions system refers to late of the 19 the and 1880. the first suggestion system applied by general electric company in America at 1906, that was involved suggestions box in any part of company and employees to throw their practical suggestions in it, in order to production's improvement. In according to company's report that was published in 1968 ' the company was paid $14295387 \$$ to employees for their suggestions (247129 suggestions)

Bright results of establishment of suggestions system in developed countries and even in some of Iranian companies is clear. Matsoshyta Company in Japan with receiving of six million suggestions in 1985. Had been acquired the first position in the world. In Iran kontorSazi Company has applied this system since 1989, and received 14940 suggestions in 1998, and performed 1196 suggestions.

After 1998 behalf Iran's parliament (establishment of suggestions of suggestions system)consider as the first stage in establishment of cooperative management, and wanted of all of executive organizations that provide necessary conditions for establishment of suggestions system and with regard to importance if employees cooperation in progress of efficiency and effectiveness of executive organizations and increasing of their ability and approval to take action for establishment if suggestions system(Management culture, 13 number). 
Kermanshah province Ministry of Education also , for taking personage ,solving of problem by manpower, profiting of mental creativity and employees abilities and also in according to Iran s parliaments' letter in about of establishment of suggestions system in department established this system.

\section{RESEARCH HYPOTHESIS}

The main question in this research is « what are the barriers of implementing of recommendation organization in Ministry of Education in Kermanshah? In answering to this question what are the most important barriers of implementing of recommendation organization from the perspective in ministry of education in Kermanshah? And how are their sequence and priority? Four hypotheses are as follow:

H1: barriers from staff act as main barrier of implementing of recommendations organization in management.

H2: organizational barriers no impact in implementing of recommendations organization of participative management.

H3: management barriers in implementing of recommendations organization act as second factor.

H4: structural and cultural barriers in implementing of recommendations organization are the third factor.

\section{RESEARCH METHOD}

This research is descriptive- surveying. Because this research surveying the existing state of affairs known as descriptive research and because surveying the opinions by questionnaire known as surveying research . In this method a sample of employees to choose by kokaran model and then to survey it by use of questionnaire and were distributed among statistical sample. In this research had been used of freed man test, and also had been used of graphs, mean, standard deviation, spss program and etc.

\subsection{Statistical society and Research sample}

Statistical society is some of favorite elements that have a special feature, that mean they have a same feature which to separate them of the others. (Azar and et.al 2002).

Our statistical society is 26550 employees that work in Kermanshah province Ministry of Education. Table 1and 2and 3 show:

\begin{tabular}{|c|c|c|c|c|c|c|}
\hline Degree & $\begin{array}{c}\text { Master of } \\
\text { science }\end{array}$ & Bachelor & $\begin{array}{c}\text { Upper } \\
\text { Diploma }\end{array}$ & Diploma & $\begin{array}{c}\text { Pre } \\
\text { Diploma }\end{array}$ & total \\
\hline number & 2445 & 11142 & 8643 & 3774 & 536 & 26550 \\
\hline
\end{tabular}

Table 2: total number of research population by age

\begin{tabular}{|c|c|c|c|c|c|}
\hline age & $20-30$ & $31-40$ & $41-50$ & $51-60$ & total \\
\hline number & $23 \%$ & $36 \%$ & $28 \%$ & $13 \%$ & 100 \\
\hline
\end{tabular}

Table 3: total number of research population by sex

\begin{tabular}{|c|c|c|c|}
\hline sex & female & male & total \\
\hline number & $44 \%$ & $56 \%$ & 100 \\
\hline
\end{tabular}

So we observed two conditions for sampling: to be enough of sample and the chose's chance for any people to be similar .In this research for sampling we used of casual sampling. first the sample volume calculated by use of kokaran method, then on the basis of distribution of statistical society among different degrees, we divide sample volume among them on the basis of kokaran method number of sample calculate as

following: $\quad n=\frac{N Z^{2} \cdot p \cdot q}{N e^{2}+z^{2} p \cdot q}$

In this research trust co efficient was $\% 95$ (equal value with $\% 95$ trust coefficient is 1.96 ). Lawful error was $\% 7$, and with attention to non-disposal to values' variance, the maximum of variance considered $\mathrm{p}=0.5$. With substituting of above values in kokaran equation and chosen of 195 people as statically society, $\mathrm{n}$ calculate as follow

$$
N=\frac{26550(1.96)^{2 \cdot *(0.5)(0.5)}}{26550(\% 7)^{2}+(1.96)^{2} *(0.5)(0.5)}=194.57=195
$$

Above mentioned number divide between them in relation to degrees. Statistical sample with regard to degree's separation has been shown in table 4: 
Table4: distribution of statistical society and chosen samples

\begin{tabular}{|c|c|c|}
\hline Degree & Statistical society & Statistical sample \\
\hline Pre-diploma & 536 & 4 \\
Diploma & 3774 & 30 \\
Upper- diploma & 8643 & 59 \\
Bachelor & 11142 & 81 \\
Master of Science & 2445 & 21 \\
\hline total & 26550 & 195 \\
\hline
\end{tabular}

\subsection{Data collecting tools}

For data collecting we used of interview and questionnaire. With regard to answer about research and after study in theoretical subject and also to interview experts and masters in Kermanshah province ministry of education, we find the most important obstacles of establishment of suggestions system and also to identify the suitable bed for them, and on the basis of these information's designed a questionnaire that include 3 part: first part related to public questions of tester, in second part question had 5 choice and the list of obstacles(managing, employees, systemic and cultural obstacles) involved 28 questions and asked of tester that answered the questions With use of his experience and determined effectiveness of obstacles in establishment of suggestions system . in third part for knowing that is there suitable bed for establishment of suggestions system and employees that stated his ideas. For designed hypothesis test. There had many questions that some of them to near to reality and some of them was related to people views, for data collecting had been used of questionnaire, all of the questions were closed kind and on the has is of Likrat standard.

\section{STATISTICAL METHOD FOR ANALYZING OF DATA}

In this research had been used of freed man test, and also had been used of graphs, mean, standard deviation, spss program and etc.

\subsection{Freed man test}

When data that related to regular sample of group $\mathrm{k}$ be in serial scale, is using of freedman test for analysis of mutual variance. We used of this test for measuring, and we there group haven ${ }^{\text {tt }}$ different or not. First data divides in a table ha $\mathrm{n}$ range and $\mathrm{k}$ column. Ranges are index for testers and columns are a index for different choices. Freedman test determined that wither volume result (Rib(s) ) have different meaningless or not. For using of this test calculates a statistical value that freedman show it box. When the number of ranges and column be large can show that $\mathrm{x}$ has a distribution which is equal with $\mathrm{k}-2$ and degree of def. $=\mathrm{k}-1$.

$$
|R j-R i|\rangle t i--{ }_{z}^{\propto}\left[\frac{2 N(A 2 B 2)}{(N-1)(K-1)}\right]
$$

\section{ANALYSIS}

The main question in this research was «what are the most important obstacles of establishment of suggestions system in Kermanshah province ministry of education?

For answering to this question, was used statistical view about 4 main obstacles of establishment of suggestions system. Deductive statistic parametric test:

Test's test a many 4 obstacles of establishment of suggestions system.

Table5: results of test $\mathrm{T}$ about 4 obstacles

\begin{tabular}{|c|c|c|c|c|c|c|}
\hline $\begin{array}{c}\text { degree } \\
\text { of } \\
\text { freedom }\end{array}$ & $\begin{array}{c}\text { Amount } \\
\text { out }\end{array}$ & $\begin{array}{c}\text { Standard } \\
\text { error } \\
\text { mean }\end{array}$ & $\begin{array}{c}\text { Standard } \\
\text { Deviation }\end{array}$ & Mean & Number & obstacles \\
\hline 185 & 5.7906 & 0.47488 & 1.15119 & 3.45 & 186 & Managing \\
\hline 185 & 4.5903 & 0.4870 & 1.14396 & 3.25 & 186 & Systemic \\
\hline 185 & 4.4872 & 0.54577 & 1.13521 & 3.14 & 186 & Structural -cultural \\
\hline 185 & 5.9132 & 0.03953 & 1.15134 & 3.50 & 186 & Vision from employees \\
\hline
\end{tabular}

Surveying of 4 obstacles shows that obstacles that raising form employees with 3.50 mean are in the first position, managing obstacles obstacles with 3.45 mean are in second position, systemic obstacles with 3.25 mean are in third position, and structural- cultural obstacles whit 3.14 mean are in forth position. 
Table 6: results of barriers

\begin{tabular}{|c|c|c|c|}
\hline no & prioritize barriers of suggestions system & mean & Total \\
\hline 1 & Managing barriers & 3.45 & 24.15 \\
\hline 2 & Systemic barriers & 3.25 & 22.75 \\
\hline 3 & Structural-cultural barriers & 3.14 & 21.98 \\
\hline 4 & Employee's barriers & 3.50 & 24.50 \\
\hline
\end{tabular}

The table 6 shows that among 4 obstacles of establishment of suggestions system:

1. obstacles that raising from employees are the most main obstacles

2. managing obstacles are in second position

3. systemic obstacles and calls and cultural structural obstacles are in next positions

Graph 1 shows the roller bearing graph of obstacles.

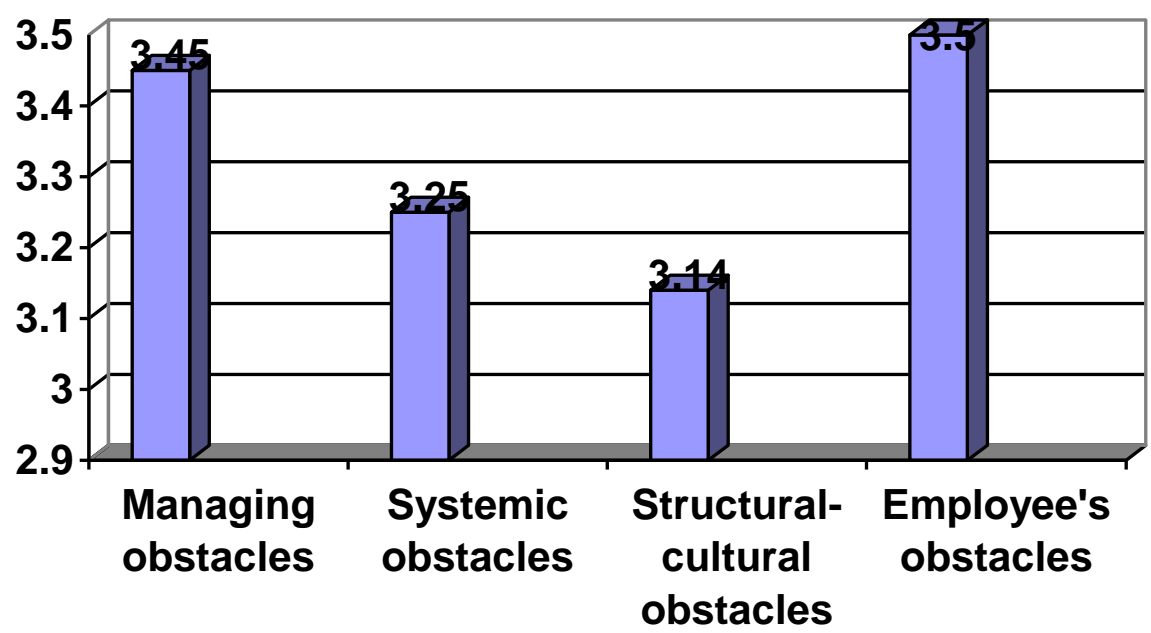

for that can generalize above result to statistical society or in other word see wet her there is any meaning full different between obstacles mean or not had been used of radiance analysis test, with attention to similarity of samples in 4 groups (managing, systemic, employees and structural obstacles) didn't same variance test

Table 7: data analysis test related to obstacles of establishment of suggestion system

\begin{tabular}{|c|c|c|c|c|c|}
\hline $\begin{array}{c}\text { Meaning } \\
\text { full level }\end{array}$ & $\mathrm{F}$ & $\begin{array}{c}\text { Square of } \\
\text { mean }\end{array}$ & $\begin{array}{c}\text { Degree of } \\
\text { freedom }\end{array}$ & $\begin{array}{c}\text { Total of } \\
\text { squares }\end{array}$ & \\
\hline 000.0 & 3.10 & 506.4 & 3 & 518.13 & Among the groups \\
\hline & & 450.0 & 20.6 & 282.279 & Inter the groups \\
\hline & & & 23.6 & 800.292 & total \\
\hline
\end{tabular}

$\begin{gathered}\text { Management } \\ \text { barriers }\end{gathered}$
\[ \begin{array}{rrrrr}16 & \begin{array}{c}\text { Barriers } \\ \text { from staff }\end{array} & \begin{array}{c}\text { Organizational } \\ \text { barriers }\end{array} & \begin{array}{c}\text { Cultural and } \\ \text { structural } \\ \text { barriers }\end{array} & \begin{array}{c}\mathrm{k}= \\ 1 / \mathrm{Ln}(\mathrm{m})=0.621\end{array} \\ & 19 & 25 & 15 \\ 43 & 33 & 30 & 29 \\ 54 & 50 & 52 & 48 & \mathrm{Pij}=\mathrm{aij} / \sum \text { aij } \\ 186 & 52 & 56 & 52 & \mathrm{P} 11=0.087 \\ \mathrm{P} 21=0.177 \\ \sum=186\end{array} \]

so with coefficient $99 \%$ trust con claim that the most important barriers of implementing recommendation organization from staff with 3.50 mean and then management barriers with 3.45 mean are placed in other categories based on organizational barriers and cultural and structural barriers. In order to confirm of above ranking with use entropy method as follow based on table of number 8 conclude that prioritize entropy method is similar to Friedman hypothesis test. 


$$
\text { Ej }=-\mathrm{k} \sum \text { Pij Ln Pij } \quad W j=d j / \sum d j
$$

Table of number 8: prioritize based on entropy method

\begin{tabular}{|c|c|c|c|c|}
\hline factor & $\begin{array}{c}\text { Management } \\
\text { barriers }\end{array}$ & $\begin{array}{c}\text { Barriers } \\
\text { from staff }\end{array}$ & $\begin{array}{c}\text { Organizational } \\
\text { barriers }\end{array}$ & $\begin{array}{c}\text { Cultural and } \\
\text { structural } \\
\text { barriers }\end{array}$ \\
\hline $\mathrm{Ej}$ & 0.957 & 0.961 & 0.954 & 0.951 \\
\hline $\mathrm{Wj}$ & 0.24 & 0.22 & 0.26 & 0.28 \\
\hline priority & 2 & 1 & 3 & 4 \\
\hline
\end{tabular}

\subsection{The main hypothesis:}

barriers from staff act as main barrier of implementing of recommendations organization in management. For confirm or reject first hypothesis claim used from Friedman test based on indicate results in 8 tables obvious that researcher claim accept at 95\% level and the effect is as follow of 9 tables.

Table 9 ranking barriers of implementing use of Friedman ranking test.

\begin{tabular}{|c|c|}
\hline factor & rank \\
\hline Barriers from staff & First \\
\hline Management barriers & Second \\
\hline Organizational barriers & Third \\
\hline Structural-cultural barriers & Fourth \\
\hline
\end{tabular}

6.2. Second hypothesis: organizational barriers no impact in implementing of recommendations organization of participative management. For confirm or reject first hypothesis claim used from Friedman ranking test and entropy method based on indicate results in 9 table obvious that second hypothesis is not meaning less.

6.3. Third Hypothesis: management barriers in implementing of recommendations organization act as second factor. For confirm or reject third hypothesis claim used from Friedman test based on indicate results in 8 tables obvious that researcher claim accept at $95 \%$ level and the effect is as follow of 9 tables.

6.4. Fourth Hypothesis: structural and cultural barriers in implementing of recommendations organization are the third factor. For confirm or reject test of fourth hypothesis claim used from Friedman ranking test and entropy method based on indicate results in 9 table obvious that fourth hypothesis is not meaning less.

\section{RESULTS OF RESEARCH}

In this research barriers of implementing of suggestion system were survived from 4 dimensions of management, organization barriers, structural- cultural and barriers from staff that important result of research are as follow:

1. In the basis of views of statistical society, the most important obstacles in department are rising from employees and to be confirmed as first hypothesis and managing, organization barriers and structural - cultural barriers are in the next degrees.

2. In Organizational barriers group, of recommendations in implementing recommendations organization of participative management as third priority so in this group second hypothesis to be rejected.

3. management barriers of recommendations organization as second priority are deterrent factor recommendations organization from point view of staff and appertain to indexes: lack of managers riskiness, manager`s believe to suggestions system and conflict in managing methods, so the third hypothesis to be confirmed.

4. In structural -cultural barriers group the most obstacles are: the extent of department, complexity of organization duties that to limit suggestions back ground and inattentive to managing and exerting education, so the forth hypothesis to be rejected.

5. for any of 4 hypotheses hypothesizes by use of statistical methods and test, bed been confirmed first, second third and fourth hypothesizes and fifth hypothesis had been refused.

\section{CONCLUSION}

Generally acquired results of data analysis show that use of cooperative management (suggestions system) in Kermanshah province ministry of education will have important role in department. On the basis of finding $\mathrm{s}$, for enjoyment of suggestions system advantages it is necessary that managers to be familiar whit suggestions system advantages via suitable learning, for this purpose that manager to come to believe to suggestions system and supports of it. Whereas collective decisions. will increase of employees, which whit to respect to their personality and providing of suitable conditions for showing of their abilities and their talents, these aims to be carry . 
One of the most important factors of resistance against changes and systemic decisions in employees is lack of knowledge about making a decision process and they fell that they haven`t effect and role in department so establishment of methods and suitable ways on behalf of managers that to increase their knowledge. Can be effective in deceasing of resistance.

Suggestions system can be effective role in educational departments, and generally findings of this research show that suggestions system has been effective in Kermanshah province ministry of education but employees'

satisfaction of establishment of wasn 't, so it is necessary that manager have believe to suggestions system and whit omission of Borocratic culture, try that to replace it`s by a worthy system and to increase managers riskiness and to them and planning. It is necessary that to improve, communication clearing of aims and duties in department, education of people, rotator information system and exact survey, because this factors to increase success, degree of suggestions system. Whit regard to extent of cooperative system in this research we survived only suggestions system of inters systemic obstacles. Comparing of these results show that finding of these research are same whit previous studies.

\section{SUGGESTIONS}

On the basis of finding of this research in establishment of suggestions system in Kermanshah province ministry of education the below suggestions to offer:

1. Suggested that information system will be fined formation different parts of department to offer to employees. This information to be offer to employees by establishment of working team.

2. The promotion of collective worked in department via establishment of motivation and trust atmosphere and establishment of working team.

3. Distribution of suggestion results that employees offered and publication of saving results and vast advertisements.

4. For suggestions' satisfaction and understanding of suggestions to be use of internal and external experts, to be attention to forming of exerting team and to be try that to survey suggestion in exerting group

5. The results of research show that lack of efficient employees in suggestions system committee to cause that system to be inefficient and be suggested that established learning course for committee and experts.

6. Duties, positions to be clear and define so that employees know their duties.

7. For rein forcing of managers. Employees and experts, should beaten tin

8. In seminars and meetings, to be offer suitable suggestions for manager's so that to increase managers riskiness and to thank of suggestions'.

9. For institutionalizing and establishing of suitable bed it is necessary the management and to replace other managing methods.

10. For establishment of suitable bed for manager`s support of suggestions system, can establish educational backgrounds and to encourage manager`s that applying cooperative management. This is one of the most important items in suggestions system and manager`s should establish it in department and to increase manager `s believe.

\section{REFERENCES}

[1] Ahanchi, M. (2008). Strategic management. Dustan publication. First Edition. Tehran.

[2] Ahangari, S. \& Amirzadeh, S. (2011). Exploring the Teachers' Use of Spoken Corrective Feedback in Teaching Iranian EFL Learners at Different Levels of Proficiency. Procardia - Social and Behavioral Sciences, 29, 1859-1868

[3] Amazonian, M. R. (2000). Serving of effects of establishment of cooperation managements system. Management knowledge Journal. N 49: 23-32

[4] Anderson, C.R. (2004). Management: Skills, Function, and Organization Performance, 2nd ed., Boston: Allen and Ban Com.

[5] Atwater, L.E., \& Brett, J.F. (2005). Antecedents and consequences of reactions to developmental $360^{\circ}$ feedback. Journal of Vocational Behavior, 66(3), 532-548.

[6] Darker, P. (2005). Management Challenges in 21 century. Translated by Toloua, M. Cultural services. Tehran.

[7] GAO, L. Janssen. O. \& Shi, K. (2011). Leader trust and employee voice: The moderating role of empowering leader behaviors. The Leadership Quarterly, 22(4), 787-798.

[8] Ghasemi, M. R. (2004). Thesis M.A. Surving of effects of establishment of cooperative management in Water and sewage department of Khuzestan province. Management education Institute College. Khuzestan.

[9] Heresy, P. \& Blanchard, K. (2001). Management of organization. Behavior: Utilizing Human Resource. New York, Prentice - Hall International Edition, Fifth Edition. 
[10] Hersy, p. C. (2006). Systemic behavior management. Translated by Alaghe Band, A. Amir Kabir publication. Tehran.

[11] Hossaini, N. (2005). Thesis M.A. Surving of effect of establish meant of suggestions system on employees act in financial and administrative assistance. Of Iran communications, Management college of Tehran.

[12] Iran Nejad, farizi. M. (2006). Research methods in social science. Modiran publication. Tehran (in Persian).

[13] Jun, M., CAI, S. \& Shin, H. (2006). TQM practice in maquiladora: Antecedents of employee satisfaction and loyalty. Journal of Operations Management, 24(6), 791-812.

[14] Karimi, H. R. (2001). Thesis M.A. Surving of effect of establishment of cooperative management system via employees suggestions system on increasing of profiles in electricity department of Fars province. Shiraz University. Shiraz.

[15] Milner, E., Kennel, M. \& Usher wood, B. (1995). Employee Suggestion Schemes: a management tool for the 1990s? Library Management, 16(3), 3-8.

[16] Mohammad Ali poor, A. A.(2005) Thesis M.A. Surving of obstacles of establishment of cooperative suggestions system in Qom Industries. Tehran.

[17] Pirayesh, R., Niazi, R. \& Ahmad khani, A. (2012). Investigating the effective factors on management internal controls applying. Management Science Letters, 2(4), 1203-1208.

[18] Plonket, L. (2003). Cooperation management. Translated by Those, M. A. Governmental management's publication. Tehran.

[19] Rabinz, E, B. (2005). Systemic behavior. Translated by Persian, A. \& Arabia, and M. cultural researches publication. Tehran.

[20] Recht, R. \& Wilderom, C. (1998). Kaizen and culture: on the transferability of Japanese suggestion systems. International Business Review, 7(1), 7-22.

[21] Richard, L. D. (2006). Departments theory and desing. Translated by Persian, A. \& Arabia, and M. cultural researches publication. Tehran.

[22] Shaykh Mohammadi, M. (2000). Thesis M.A. Necessities of suggestions system for effectiveness. Esfahan's Industrial University. Industries Engineer College. Esfahan.

[23] Sohrabi, A. (2006). Thesis M.A. Survey and knowledge of challenges of establishments of suggestions system in Iran governmental departments. Qom. (In Persian).

[24] Vakil Alroaia, Y. \& Najafi, Z. (2012). Performance measurement of employee using an integrated $360^{\circ}$ feedback system and AHP method: A case study of municipality. Management Science Letters, 2(5), 1655-1660. (In Persian).

[25] Wood, J., \& Schmaltz, L.M. (2004). Patient, faculty, and self-assessment of radiology resident performance: A360-degree method of measuring professionalism and interpersonal /communication skills. Academic Radiology, 11(8), 931-939.

[26] Yi, Y., Nataraajan, R., Gong, T. (2011). Customer participation and citizenship behavioral influences on employee performance, satisfaction, commitment, and turnover intention. Journal of Business Research, 64(1), 87-95

[27] Yosefi, kh. H. (2004). Thesis (M.A). Knowing of systemic obstacles or suggestions system of employees $\mathrm{s}$ view in electricity department of Azerbaijan. Tehran. 